\title{
Development Aspects Of Business Embroidery Craft Enni Design In Bukittinggi
}

Ratni Prima Lita, Meuthia, Surya Sari, Debi Shintya Dewi

Management Study Program

Faculty of Economics, Andalas University

ratniprimalita@eb.unand.ac.id

\section{ARTICLE INFO}

keyword:

Business aspects, SMEs

\begin{abstract}
$A B S T R A C T$
Community service Carried out at Enni Design in the city of Bukittinggi aims to expand the business by paying attention to aspects such as production, products, management, human resources, and facilities. Enni Design's business is expected to be Able to Increase product differentiation from competitors, improve HR capabilities in designing motifs and colors that follow fashion trends, improve human resource capabilities in preparing financial reports, and Utilize waste valuable economically. After training and innovation practices, businesses are given the opportunity to consult or discuss existing business opportunities and design strategies. The results of the training of partners show that they are Able to understand what differentiates Reviews their products Compared to competitors. In addition, it is also able to compile financial reports in accordance with accounting principles, and can manage waste into new products that are worth selling.
\end{abstract}

\section{Introduction}

Creative industries sector became one of the industries which have a fairly rapid growth. This is evident from the creative industry's contribution to gross domestic product (GDP) in the last three years continue to rise. The creative industries accounted for only Rp 852 trillion in 2015, then increased to Rp 923 trillion in 2016 and Rp 990 trillion in 2017, and in 2018 is estimated to reach Rp 1,000 trillion (Kompas.com). Another advantage of the creative industries as an industrial sector which is labor-intensive, ie more than 18 million people in 2018 (Kompas.com).

According to the Head of the Creative Economy (Bekraf) there are three main sub-sectors of creative economic growth in Indonesia, namely culinary, fashion, and craft (beritagar.id). 700 thousand small and medium enterprises engaged in handicraft products sector, there are about 1.3 million workers absorbed. Creative industries must continue to innovate, both in terms of products, packaging, selling brand reinforcement (brand), and marketing techniques. Online media is one way that can be utilized entrepreneurs to develop their business. It aims to provide convenience for the buyers, especially foreign buyers, which can buy local handicraft products without having to come directly to the site.

In West Sumatra, the creative industries are still difficulties in aspects of marketing, lack of capital for production, management and financial management are not well ordered (kabar24.bisnis.com). But behind these difficulties, the development of domestic industries such as embroidery, weaving and Minangkabau songket has worldwide (Kinciakincia.com). As local cultural industries and labor-intensive, embroidery, embroidery, weaving and songket growing in some counties and cities, like in Bukittinggi, Payakumbuh, Sawahlunto, Sijunjung, Limapuluhkota, 
Padang Pariaman, Agam and Tanah Datar. Each area offers unique patterns and shades of different motives.

As a region rich in needlepoint and embroidery, currently there are 335 units of embroidery artisan business in Singapore has nurtured (sumbar.anatarnews.com). One of them is Enni Design, which has stood since 2006 in Jl.Angkatan 45 Tarok Dipo Bukittinggi. Some of the problems faced by "Enni Design", namely in the fields of production, product, management, human resources and facilities. Constraints in the areas of production such as difficulty in penyocokan thread, hard to find yarn and thread color adjust craftsmen and sometimes not in accordance with the order. In addition, the processing of industrial waste that has not been optimally utilized economically as the rest of the fabric which is quite a lot. Though it can be processed into accessories, wall decoration and so on.

When this type of product produced "Enni Design" there are as many as 7 different. With such a product variant suits ladies dress material, a blouse, a robe, a kebaya, gloves, scarves, hijab. Total production per month with the specifications of each product which suits clothing products 60 units / month, 40 material embroidery and embroidery, and 20 pieces of apparel. Products produced are with medium and high quality / good for consumers and the upper middle segment. Product differentiation has begun to appear. But still need to be developed is unique, so it can compete in the market. Another obstacle in fields such as fashion products is still limited and the lack of information about fashion trends.

Conditions still conventional management. Production planning has been created and compiled for one month. Preparation of bookkeeping already started doing that cash flow in the form of money coming in and money going out. Constraints faced "Enni Design" in the field of management that no statements based on accounting principles, either manually or using the software, so that employers are less get an overview of their business development. In addition, the tax has not received the training but already have a TIN. Currently the brand "Enni Design" has not been registered to the Institute of Intellectual Property. No auditing (inspection) from independent parties on the financial statements and accounting firms, because employers have not prepare financial statements in accordance with accounting principles. Product inventory is kept for the next six months, due to limited business capital.

Constraints in the field of human resources is still limited information about fashion trends. HR has the skills in the financial sector does not exist. The owners have training use of the Internet for marketing, production and design are arranged by the Government through the Department of Trade, Industry and Cooperatives. Continuous training is still limited but is followed by employers. In terms of facilities, owned storefront now not so attractive and adequate, making it less able to memajangi products with attractive.

Research (Lita, Meuthia, And Faisal 2018) in West Sumatra shows that product innovation is still limited to SMEs, including embroidery and stitching "Enni Design". Craft industry has great market potential, not only locally and nationally, but has expanded into the international market. This is consistent with the results of research Lita (2008) and Lita pegabdian activities and Surya (2012), as well as (Lita and Faisal 2018), But there are still many problems experienced by SMEs on the business aspects of business such as product, production, business management, human resources, and facilities.Pengembangkan performance of SMEs must consider the aspect of human resource capacity and the preparation of financial statements, so that SMEs survive and be competitive both nationally and globally (Harahap 2014).

In addition to considering these aspects, the attitude of the business owner is also very important as a determinant of business advancement. According to (Lita, Meuthia, And Faisal 
2018) overall leadership has an important role in driving business success, because the leadership indicate whether or not the business forward including craft businesses Enni Design. This shows that the craft products remained in the interest of customers despite using pre-existing motifs like the needlepoint and embroidery craft. The uniqueness of the Minang or a typical product of West Sumatra are even more customer attention. This craft business must understand customer needs, improve product quality and service, responding to customer complaints, adjusting the resulting product to the changing needs of customers in order to optimize customer satisfaction.

Market-oriented craft industry needs to encourage better organizational performance. Market orientation makes businesses find out what consumer tastes, product opportunities in the marketplace and how a company improve its product value compared to competitors, and with regard to resources and competitors. Market-oriented organizations drive innovation and improve company performance (Lita and Faisal 2018).

Innovation is the key to success in business growth that occurs. Product innovation effect on business development. The reality is the crafts business, product innovation does have an influence on business growth. So the owner of the craft should be able to create innovations in its products, mainly to obtain the targeted profit orientation. If in the handicraft businesses are no actions in the form of innovation, then it is likely the business will decline.

Product innovation is an activity that creates new products, aims to meet market demand and increase profits (Damanpour 2010). For stakeholders in a business, product innovation can be easily recognized. This is in accordance with the results of the study Karabulut (2015) abortion study which also stated that product innovation is easily recognized by stakeholders in the business. To be able to compete in the market, every business needs to carry out continuous research and development. Another definition of product innovation is a series of activities that require a lot of resources, and make producers face many challenges. The reason is that most businesses still lack financial and technical resources, skills, poor management skills, and uncertain institutional aspects. (Guo, Xu, \& Jacobs, 2014; Sheng, Zhou, \& Lessassy, 2013).

From the background and situation analysis conducted at the craft business Minang Enni Design, the authors are interested perform service activities on "Development Aspects of Business Embroidery Craft Enni Design in Bukittinggi".

\section{Theoretical Framework}

Innovation can be interpreted as the use of new ideas or ideas into products, processes and other aspects of business activities. Innovation that is centered on the process, aims to connect ideas into things that are worth considering. Innovations can be grouped into five namely new products, new production methods, new sources of supply, new ways or techniques in managing business. Overall, product innovation is used in the company's operations.

Radically, product innovation is expected to be able to maintain the position of SMEs in the market. In other words, SMEs have an important relationship with customers. In addition, process innovation is aimed at increasing the competitiveness of SMEs and reducing production costs. Strategic capabilities such as research and development (R \& D) are studied as a determinant of the course of innovation (Raymond and St-Pierre 2010). Product innovation is important for business action, which is a key condition for business success. This is considered as a condition that must be taken by businesses to gain competitive advantage (Cho et al. 2018).

According to Yusof, Roddin, \& Awang (2015), the transformation of knowledge into new processes, products, and services is a form of influence from product innovation. Another definition of innovation is the application of ideas and ideas to products, processes, and other aspects. Innovation is a different view focused on improving technology and developing products 
from Yeşil, Koska, \& Büyükbeşe (2013). Business performance is derived from the ability of innovation through various types of innovation. Innovation is required to use production and marketing technology to produce new products and services to consumers through new product attributes. Panigrahy \& Pradhan(2015) suggested that innovation is a new idea of combining old ideas that are considered as something new unique, then developed internally. Corporate innovation aims to involve generations and take new ideas and behaviors, so that they are formed into new products or services.

Based on the literature of Schreiber et al. (2016), Yusof et al.(2015), Yeşil et al.(2013) and Panigrahy \& Pradhan (2015) then Kuncoro \& Suriani (2017) can conclude that product innovation that is defined as innovation can be used in all of the company's operations a new product is made and marketed, including innovation in all processes related to it. Product innovation is expected to continue to be able to increase business performance. The optimal level of difference in resources must be in the middle range, so that a pool of resources from producers and suppliers is differentiated properly to ensure complete resources. And so there is no overlap in order to be able to facilitate the identification and integration of complementary resources (Bao et al. 2017).

Institutional support is defined as a general reflection of financial and technical support from the government and other institutions, offering important resources that are useful for innovation and development. Institutional support is considered as an important provider of external resources. It aims to encourage the development of new products and policies, as well as favorable regulations and protect intellectual property rights and reward innovators through giving legitimacy (Zhang, Sun, and Li 2017).

(Li and Ding 2017) in his research explained that institutional support has the role of influencing the internationalization of business in many ways. This is realized through the provision of SME assistance to obtain important information, reduce the risk of internationalization, and access additional business opportunities through government bilateral trade partnerships. SMEs can take advantage of financial support provided by government policies. The government also provides information services regarding foreign business, environment and investment opportunities. The involvement of the government in foreign investment activities, the SMEs can trade contracts more easily and alleviate the commercial and political risks they face in foreign markets.

Based on research (Buhr and Owen-Smith 2010), it was concluded that there was a strong bond. Where institutional support crosses SMEs to facilitate the development and maintenance of reciprocity, trust, and good collaborative routines. In other words, this can reduce the costs and uncertainties and risks of new businesses. General entrepreneurial expertise through a cooperative approach from local investors and counselors, will have an impact on the ability to facilitate easy transitions throughout start up in several businesses.

Knowledge is defined as the ability or expertise developed by all individuals to capture and process information about their environment. Although the knowledge of each person is different, what is most relevant will be shared and integrated into the business. The ability to combine knowledge is divided into knowledge exchange between individuals and work groups. This allows the transfer of knowledge in the organization and its application to the development of new products. A combination of good and high level of knowledge will produce more innovative products (María Ruiz-Jiménez and del Mar Fuentes-Fuentes 2013).

Knowledge combination capability requires innovative use and form of knowledge. During the problem solving process, businesses or SMEs can access and use external knowledge, even combining it with internal knowledge. Therefore, joint problem solving is a program for SMEs to 
experiment through various types of knowledge integration (Zheng, Zhang, and du 2011). The results of the study (Mao, Liu, and Zhang 2014) explain that the knowledge combination capability is considered as the ability of organizations to mobilize and disseminate knowledge-based resources, and be combined with other capabilities to gain business value and gain competitive advantage.

In addition, an important aspect that needs to be considered is organizational innovation. (Ho 2011) describes organizational innovation as a collection of five dimensions namely creativity, risk taking, openness to change, future orientation, and pro-activity. (Fernandes Rodrigues Alves, Vasconcelos Ribeiro Galina, and Dobelin 2018) explains that organizational innovation is considered a change in organizational structure and processes, administrative systems, knowledge used in conducting management work, and managerial skills that enable organizations to function and succeed in using resources owned dayan effectively.

Organizational innovation can be aimed at improving company performance, by reducing administrative costs or transaction costs, increasing satisfaction in the workplace (for example labor productivity), gaining access to non-tradable assets (for example external knowledge that is not codified) or reducing inventory costs (Trusson, Hislop, and Doherty 2017). The argument related to organizational innovation is access to external knowledge, the choice to divide the costs and risks of an innovation process or there is no innovation, access to skilled workforce in the external environment (Barroso Simao, Gouveia Rodrigues, and Madeira 2016).

Research (Sutanto 2017) shows that organizational innovation is a variable used for new ideas, behaviors, products, services, technology, and administrative practices, to stimulate processes and practices in organizations for the purpose of innovation. (Pauget and Wald 2018) divides organizational innovation into three groups: structural characteristics of innovative organizations, organizational change and the emergence of organizational innovation from micro-level structures and processes. Organizational innovation helps increase the company's capacity to develop new forms of marketing, so that their products can adapt to new markets and able to face uncertainty in the organization (F. Javier Ramirez, Gloria Parra-Requena, Maria J. Ruiz-Ortega 2016). Organizational innovation is also defined as implementing new methods in organizations through business practices. In addition, organizations are considered as workplaces or external relations that have not been used before (Gallego, Rubalcaba, and Hipp 2013).

\section{Research methods}

Service activities is carried out through three stages:

1) Preparation Activity

In the preparatory stage 4 activities, namely:

a. Socialization and permits with the relevant institutions.

b. Contacting employers to decide the schedule of activities.

c. Develop training modules.

d. Preparing for the implementation of activities.

2) Implementation Activities

Method of activities used to resolve the problems facing entrepreneurs is a method of training, consulting and practice. In detail seen in Table 1: 
Table 1. Methods of Problem Solving Solutions Event

\begin{tabular}{|l|l|}
\hline \multicolumn{1}{|c|}{ Solution Troubleshooting } & \multicolumn{1}{c|}{ The method used } \\
\hline Increase product differentiation from competitors & $\begin{array}{l}\text { Training methods and practice of } \\
\text { product innovation }\end{array}$ \\
\hline $\begin{array}{l}\text { Enhance human resource capabilities in the design } \\
\text { motifs and colors that follow fashion trends }\end{array}$ & $\begin{array}{l}\text { Methods of training, practice and } \\
\text { consultancy }\end{array}$ \\
\hline $\begin{array}{l}\text { Enhance human resource capabilities in the financial } \\
\text { statements based on accounting principles, so it could } \\
\text { be in auditing financial statements to see an overview } \\
\text { of business development. }\end{array}$ & $\begin{array}{l}\text { Methods of training, practice and } \\
\text { consultancy }\end{array}$ \\
\hline Increased clothing and soevenir with waste utilization & $\begin{array}{l}\text { Training methods and practice of } \\
\text { product innovation }\end{array}$ \\
\hline
\end{tabular}

3) Monitoring and Evaluation

After the activity is done, then held a monitoring and evaluation activities are as follows:

a. Evaluation of the implementation of activities, by comparing the results of pre-test to post-test, the number of designs and products.

b. Monitoring the implementation of activities

c. Report on the implementation of activities

\section{Finding}

Enni Design is a small business that produces embroidery and embroideries with the application of various fabrics such as batik and woven and sewing clothes for the consumer. These businesses since 2006. At the beginning of the sales turnover stood around Rp.8.500.000 per month and continues to experience an increase in sales from year to year. In 2011 this business has developed rapidly with a turnover of Rp.16.000.000,00 per month. In 2016 the sales turnover of around Rp.20.000.000-Rp.30.000.000 per month (Rp.300.000.000 / year). The following analysis of the situation in the business of embroidery and needlework Enni Design:

\section{A. Raw material}

1. Raw materials used in the Embroidery and Embroidery Business "Enni Design" is yarn, fabrics, trimmings / accessories.

2. Source materials come from suppliers in the market Aur Kuning (Bukittinggi) and fabric shops in Jakarta with a pretty good quality and in accordance with the specification requirements of the product.

3. Quality materials and yarn be divided into two types of medium and high quality / nice. Raw material supply is highly dependent on suppliers who are in London and there are no alternative suppliers from other regions or search directly to the manufacturer.

\section{B. Production}

1. Production is hand made embroidery and patchwork which can also be combined with other fabrics such as batik and woven with a production capacity of 60 strands / month with details of 40 pieces of clothing and 20 pieces of material that can be sewn. Especially for embroidery sewing process, entrepreneurs in collaboration with artisans (sewing children) are already known and trained by Mrs. Eni Murnisari. Control of the production process is done by direct supervision by the owners and is currently finishing by the owner and management (Eni Murnisari). 
Control of production processes performed at each stage of the production process:

1) The initial phase of supervision on the measurement of material and cutting material. This process must be ensured in accordance with the specifications of the product.

2) Supervision in the design motifs and colors of yarn used to produce the product.

3) Supervision in the process of sewing. Controlling a bit difficult due to the tailor ( "children sewing"), which are located not adjacent to the location of the business, while being produced at a place of business conducted surveillance at every stage of sewing. To resolve this issue made product samples and patterns of clothing so that craftsmen can imitate by replacing the thread variation, the motives in accordance with the order.

4) Supervision in finishing products ie check whether the stitches are neat and in accordance with the specifications of the expected and do the packaging so that the product more presentable.

a. Difficulties that are often encountered in penyocokan thread, hard to find yarn and thread color adjust craftsmen and sometimes not in accordance with the order.

b. Treatment of industrial waste that has not been optimally utilized economically as the rest of the fabric, which is quite a lot. Though it can be processed into accessories, wall decoration and so on.

c. The investment value of the initial attempt (in 2006) about Rp40,000,000.00. 2007 buy car Rp.60.000.000,00. Black sewing machine 3 pieces (Rp.1.000.000,00), white machine 2 units (Rp.4.000.000,00), engine obras (Rp.1.000.000,00), motorcycles (Rp.15.000.000, 00), mobile phones (Rp.2.000.000,00), laptop (Rp.5,000.000,00). Venture capital around Rp.12.000.000,00. Investments continue to be added, in 2010 purchased two white machines for Rp.5.000.000,00 and dresform, gawangan, amounting RP.3.000.000,00. In 2016 the lease and renovation, production houses and show room and production house for Rp.20.000.000,00. The investment value of business today around Rp.150.000,00 with details of Rp.55.000.000,00 equipment, vehicle 1 unit Rp.60.000.000,00 cars, two-wheelers for Rp.15.000.000,00 and lease the building for Rp. 20.000.0000, 00 and houses concurrently Rp.600.000.000,00 worth of production space. Production is still aiming for the middle and upper segments of consumers.

d. The production process begins with the preparation of materials such as materials that have not been embroidered / embroidered, material that has embroidery and stitching. Enni design in addition to selling materials Embroidery / embroidery also produce apparel. The process after preparing the materials are pattern-making, cutting to the pattern, sewing and finishing process (mounting studs, installation of decoration, evaporation / board and others).

e. Lay-out the production process will affect the movement of people or materials. Cut materials and designs on a table or on the floor potluck followed by sewing with a sewing machine or by hand embroidered located not so regulated. The process of finishing and packaging is done back at the location of the cutting material.

f. Quality control is controlled by the business owner and ultimate control by the business owners. For embroidery materials (tailor who became a partner employers).

\section{Product}

1. When this type of product produced is 7 kinds. With such a product variant suits ladies dress material, a blouse, a robe, a kebaya, gloves, scarves, hijab.

2. Total production per month with the specifications of each product which suits clothing products to 60 units / month 40 material patchwork and embroidery and 20 pieces of apparel.

3. Products produced are with medium and high quality / good for consumers and the upper middle segment. Product differentiation has begun to appear. But still need to be developed is unique, so it can compete in the market.

4. Fashion is still limited and the lack of information about fashion trends. 
D. Management

1. Conditions still conventional management. Production planning has been created and compiled for one month. Preparation of bookkeeping already started doing that cash flow in the form of money coming in and money going out. There are no statements based on accounting principles, either manually or using the software, so that employers are less get an overview of their business development.

2. Taxation has not received training dansudah have a TIN.

3. Currently the brand "Enni Design" has not been registered to the Institute of Intellectual Property.

4. No auditing (inspection) from independent parties on the financial statements and accounting firms, because employers have not prepare financial statements in accordance with accounting principles.

5. Product inventory is kept for the next 6 months, due to limited capital

E. Marketing

1. The turnover per month around Rp.20.000.000,00-Rp.30.000.000,00. Currently focused marketing in West Sumatra, Jakarta, Surabaya, Bandung, South Sumatra (Palembang), Kalimantan and to outside the State, namely Malaysia, Netherlands, Brunei, Singapore.

2. Product marketing began assisting by employers in other cities such as West Sumatra, Jakarta, Surabaya, Bandung, South Sumatra (Palembang), Kalimantan and to outside the State, namely Malaysia, Netherlands, Brunei, Singapore. Production is distributed into the business with the establishment of fashion houses to display their products, through exhibitions and events organized by the Local Government / Center and has begun to develop marketing via electronic media such as wa and sms. Enni Design is currently not yet have a web site.

3. The selling price of clothing materials ranging Rp.250.000,00 / strands until Rp.700.000,00 / strands, Rp.50.000,00-Rp.150.000,00 hoods, scarves Rp.150.000,00-Rp350.000,00, apparel USD .250.000,00-Rp.1.000.000,00

4. The target market of Enni Design is the middle-income segment and above. Enni Design has the potential to develop because marketing products to the market for Indonesia and Malaysia, Netherlands, Brunei, Singapore continues to be tilled.

2) Human Resources

a. Qualification of human resources are divided into several groups, the management consists of one person led by education level S1 and 1 person in charge of showroom 1 with S1, tailor amounted to 15 people with a high school education S1. Total employment in this Design Enni effort as many as 17 people.

b. HR is still limited information about fashion trends.

c. HR has the skills in the financial sector does not exist.

d. The owners have training use of the Internet for marketing, production and desainyang arranged by the Government through the Department of Trade, Industry and Cooperatives. Continuous training is still limited but is followed by employers.

3) Amenities

a. The facilities were dimiki today is the first production hall on Jl. Force 45 Tarok Dipo. 1lantai building with an area of $300 \mathrm{~m} 2$. On the road Birugo Puhun No. 240 business premises consisting of showroom space with an area of $50 \mathrm{~m} 2$, administrative space with an area 10 $\mathrm{m} 2$ and a production hall with an area of $30 \mathrm{~m} 2$. The business location is on the main street in the city of Bukittinggi and access to the capital of the province is quite easy with the distance tempuh $89 \mathrm{~km}$.

b. Owned storefront now not so attractive and adequate, making it less able to memajangi products with attractive. 
c. Electrical power source is good that comes from the State Electricity Company (PLN).

Telecommunications facilities provided quite as good as with mobile communication devices (mobile phones).

\section{Discussion}

Location of business (partners) are located approximately $89 \mathrm{~km}$ from Andalas University (Padang) and approximately $1.3 \mathrm{~km}$ from the center of Bukittinggi. Location can be reached with two and four-wheeled vehicles. Paths business location accessible by public transport. This activity involved one manager or managers and two employees. This service activities involve four personnel consisting of an executive coordinator and three members implementing activities,

Activities that have been implemented starting with the initial coordination team to discuss the preparation activities, the preparation module and outcomes of activities to be achieved. This activity resulted in an action plan that will be implemented. Furthermore, socialization and obtaining a license for the activities of the relevant agencies.

Implementation of activities begins with increased product differentiation from competitors. Here held discussions to see what innovations are needed to make the product more differentiated from competitors' products. Further improvement of human resource capabilities in design motifs and colors that follow fashion trends. Partners are able to design better products with ingredients such as batik and woven products for the upper segment. So that the resulting product has diffensiasi products that can differentiate it from competitors' products. Such as needlework and embroidery motif combines the traditional with the latest motif.

Enhance human resource capabilities in the financial statements based on accounting principles, so it could be in auditing financial statements to see an overview of business development. Human resources (HR) design Enni trained in making financial reports, so Human resources able to understand and apply this knowledge. This has an impact on the ability of businesses to see their business development. Is product innovation through the development of embroidery and needlework are able to make the products more attractive to consumers.

Waste treatment embroidery and stitching to produce products that are also in demand by consumers, such as a necklace. The existence of new products derived from sewage embroidery and stitching make Enni Design revenue increases, as well as the variety of products sold also increased.

Mitra is quite active in this pegabdian activities. Contributions partners already visible starting from the preparation stage to fund this activity. They are very interested and willing to continue to improve the business by developing embroidery and needlework, as well as creating new products from waste. In this service activities, partner role in determining the schedule of activities and is active in training, discussion, practice and business consulting.

\section{Conclusion}

Preparatory activities starting in February 2018 and most have gone according to plan activities. The method used is the training, practice and business consulting.

From these activities then proposed the following suggestions:

1. The role of local governments to conduct training on an ongoing basis is expected by the partner.

2. College parties are expected to remain an evaluation of the course of business partners.

3. Disbursements are expected to be more timely.

4. Activity is expected to be implemented on time so that more optimal results. (For the delay) 


\section{Implication}

From the analysis of the situation "Enni Design" it needs efforts from all stakeholders to develop SMEs embroidery and stitching Bukittinggi, as one of the centers producing embroidery and needlework, and the market for domestic and foreign tourists. Partners need to improve and establish cooperation with local raw material suppliers and manufacturers, obtain raw materials directly from producers or manufacturers as the best alternative. In addition, they need to fix the lay-out of production and increase the appeal of the show room. Improving the ability or expertise of human resources in the field of finance. Optimizing production space. Promoting a business location.

\section{Acknowledgment}

The authors are grateful to Minister of Research Technology and Higher Education (KemenristekDikti-DP2M) which provides financial support for this research under the provision of community services program (Science and Technology for Product Export / IBPE) 2018 NUMBER: 001 / SP2H / PPM / DRPM / 2018 and Enni Design as a partner of this program.

\section{Bibliography}

Bao, Yongchuan Et Al. 2017. "Do Resource Differences Between Manufacturers And Suppliers Help Or Hinder Product Innovation Of Manufacturers? The Moderating Role Of Trust And Contracts." Industrial Marketing Management 64: 79-90.

Barroso Simao, Lurdes, Ricardo Gouveia Rodrigues, And Maria José Madeira. 2016. "External Relationships In The Organizational Innovation." Rai Revista De Administração E Inovação 13(3): 156-65.

Buhr, Helena, And Jason Owen-Smith. 2010. 21 Research In The Sociology Of Work Networks As Institutional Support: Law Firm And Venture Capitalist Relations And Regional Diversity In High-Technology Ipos. Elsevier.

Cho, Meehee, Mark A. Bonn, Su Jin Han, And Sora Kang. 2018. "Partnership Strength And Diversity With Suppliers: Effects Upon Independent Restaurant Product Innovation And Performance." International Journal Of Contemporary Hospitality Management 30(3): 152644.

Damanpour, Fariborz. 2010. "An Integration Of Research Findings Of Effects Of Firm Size And Market Competition On Product And Process Innovations." 21: 996-1010.

F. Javier Ramirez, Gloria Parra-Requena, Maria J. Ruiz-Ortega, Pedro M. Garcia-Villaverde. 2016. "From External Information To Marketing Innovation: The Mediating Role Of Product And Organizational Innovation."

Fernandes Rodrigues Alves, Marlon, Simone Vasconcelos Ribeiro Galina, And Silvio Dobelin. 2018. "Literature On Organizational Innovation: Past And Future." Innovation \& Management Review: Inmr-01-2018-001.

Gallego, Jorge, Luis Rubalcaba, And Christiane Hipp. 2013. "Organizational Innovation In Small European Firms: A Multidimensional Approach.” International Small Business Journal 31(5): 563-79.

Guo, Hai, Erming Xu, And Mark Jacobs. 2014. "Managerial Political Ties And Firm Performance During Institutional Transitions: An Analysis Of Mediating Mechanisms." Journal Of Business Research 67(2): 116-27.

Harahap, Yenni Ramadhani. 2014. "Kemampuan Menyusun Laporan Keuangan Yang Dimiliki Pelaku Ukm Dan Pengaruhnya Terhadap Kinerja Ukm." Jrab: Jurnal Riset Akuntansi \& Bisnis 14(1).

Ho, Li-An. 2011. "Meditation, Learning, Organizational Innovation And Performance." Industrial Management \& Data Systems 111(1): 113-31.

Karabulut, Ahu Tuğba. 2015. "Effects Of Innovation Types On Performance Of Manufacturing Firms In Turkey.” Procedia - Social And Behavioral Sciences 195: 1355-64. 
Kuncoro, Wuryanti, And Wa Ode Suriani. 2017. "Achieving Sustainable Competitive Advantage Through Product Innovation And Market Driving." Asia Pacific Management Review: 1-7.

Li, Fangrong, And Daniel Ding. 2017. "The Dual Effects Of Home Country Institutions On The Internationalization Of Private Firms In Emerging Markets." Multinational Business Review 25(2): $128-49$.

Lita, Ratni Prima, And Ranny Fitriana Faisal. 2018. "Sme's Performance Of Creative Industries Supporting Tourism In Indonesia: Market Orientation, Learning Orientation And Organizational Innovativeness As Determinants." Academy Of Marketing Studies Journal 22(1).

Lita, Ratni Prima, Meuthia Meuthia, And Ranny Fitriana Faisal. 2018. "Model Keterkaitan Market Orientation, Leadership, Organizational Innovation Dan Organizational Performance Pada Industri Kerajinan Di Sumatera Barat." Jurnal Siasat Bisnis 22(1): 38-61.

Mao, Hongyi, Shan Liu, And Jinlong Zhang. 2014. "Information Development."

María Ruiz-Jiménez, Jenny, And María Del Mar Fuentes-Fuentes. 2013. "Knowledge Combination, Innovation, Organizational Performance In Technology Firms." Industrial Management \& Data Systems 113(4): 523-40.

Panigrahy, Nrusingh Prasad, And Rabindra Kumar Pradhan. 2015. "Creativity And Innovation: Exploring The Role Of Hr Practices At Workplace." (March): 1-17.

Pauget, Bertrand, And Andreas Wald. 2018. "Creating And Implementing Organizational Innovation: The Role Of Professional Identity And Network Embeddedness In Healthcare Organizations." European Journal Of Innovation Management 21(3): 384-401.

Raymond, Louis, And Josée St-Pierre. 2010. "Strategic Capabilities For Product Innovation In Smes A Gestalts Perspective." The International Journal Of Entrepreneurship And Innovation 11(3): 209-20.

Schreiber, Dusan, Uélinton Telmo Ermel, João Alcione Sganderla Figueiredo, And Alexandre Zeni. 2016. "Analysis Of Innovation And Its Environmental Impacts On The Chemical Industry." Bar-Brazilian Administration Review 13(1): 56-75.

Sheng, Shibin, Kevin Zheng Zhou, And Leopold Lessassy. 2013. "Npd Speed Vs. Innovativeness: The Contingent Impact Of Institutional And Market Environments." Journal Of Business Research 66(11): 2355-62.

Sutanto, Eddy Madiono. 2017. "The Influence Of Organizational Learning Capability And Organizational Creativity On Organizational Innovation Of Universities In East Java, Indonesia." Asia Pacific Management Review 22(3): 128-35.

Trusson, C, D Hislop, And N.F Doherty. 2017. "Journal Of Knowledge Management." The Rhetoric Of "Knowledge Hoarding": A Research-Based Critique 21(6): 1540-58.

Yeşil, Salih, Alaeddin Koska, And Tuba Büyükbeşe. 2013. "Knowledge Sharing Process, Innovation Capability And Innovation Performance: An Empirical Study.” Procedia-Social And Behavioral Sciences 75: 217-25.

Yusof, Yusmarwati, Rohayu Roddin, And Halizah Awang. 2015. "What Students Need, And What Teacher Did: The Impact Of Teacher's Teaching Approaches To The Development Of Students' Generic Competences." Procedia-Social And Behavioral Sciences 204: 36-44.

Zhang, Tinglin, Bindong Sun, And Wan Li. 2017. "The Economic Performance Of Urban Structure: From The Perspective Of Polycentricity And Monocentricity." Cities 68(March): $18-24$.

Zheng, Suli, Wei Zhang, And Jian Du. 2011. "Knowledge-Based Dynamic Capabilities And Innovation In Networked Environments." Journal Of Knowledge Management 15(6): 103551. 